\title{
Kemampuan Pemahaman Matematis Melalui Strategi Think Talk Write Pada Siswa Kelas XI IPS SMA Islam As- Shofa Pekanbaru
}

\author{
Heni Rahmadani ${ }^{1}$, Zetriuslita ${ }^{2}$, Mefa Indriati ${ }^{3}$ \\ ${ }^{1}$ Student of Program Pascasarjana, Universityof Riau \\ 1,2 Lecturer MathematicsEducation, FKIP Islamic University of Rian \\ e-mail: ${ }^{1}$ heni.rahmadani7368@grad.unri.ac.id, ${ }^{2}$ \\ zetri.lita@gmail.com ${ }^{3}$ mefaindriati@yahoo.com
}

\begin{abstract}
ABSTRAK. Penelitian ini bertujuan untuk memperbaiki proses pembelajaran dan meningkatkan kemampuan pemahaman matematis siswa pada materi Limit Fungsi dan Turunan Fungsi di kelas XI IPS SMA Islam As-Shofa Pekanbaru melalui penerapan strategi Think Talk Write. Bentuk penelitian ini adalah penelitian tindakan kelas yang terdiri dari 2 siklus. Subjek dalam penelitian ini adalah siswa kelas XI IPS SMA Islam As-Shofa Pekanbaru yang berjumlah 22 orang dengan 14 orang siswa laki-laki dan 8 siswa perempuan. Teknik pengumpulan data yang digunakan pada penelitian ini dilakukan dengan teknik pengamatan, dokumentasi dan tes. Instrumen pengumpulan data berupa lembar pengamatan, dan soal tes pemahaman matematis. Data dianalisis dengan statistik deskriptif. Hasil penelitian menunjukkan bahwa penerapan strategi Think. Talk Write dapat memperbaiki proses pembelajaran dan meningkatkan kemampuan pemahaman matematis siswa dengan nilai rata-rata kelas pada tes awal, tes kemampuan pemahaman matematis I, dan pada tes kemampuan pemahaman matematis II berturut-turut $(52,43),(70,08)$, dan $(78,41)$. Selain itu, terjadi peningkatan jumlah siswa yang termasuk dalam kriteria sangat tinggi, mulai dari tes awal, pada tes kemampuan pemahaman matematis I, dan pada tes kemampuan pemahaman matematis II berturut-turut 2 siswa, 2 siswa, menjadi 9 siswa. Dari hasil penelitian di atas, dapat disimpulkan bahwa penerapan strategi Think Talk Write dapat memperbaiki proses pembelajaran dan meningkatkan kemampuan pemahaman matematis siswa kelas XI IPS SMA Islam As-Shofa Pekanbaru.
\end{abstract}

Keywords: Strategi Think Talk Write, Kemampuan, Pemahaman Matematis.

\section{PENDAHULUAN}

Menurut BSNP (2006: 2) mata pelajaran matematika bertujuan agar siswa memiliki kemampuan sebagai berikut:

Mata pelajaran matematika bertujuan agar peserta didik memiliki kemampuan sebagai berikut: (1) memahami konsep matematika, menjelaskan keterkaitan antar konsep dan mengaplikasikan konsep atau algoritma secara luwes, akurat, efesien, dan tepat dalam pemecahan masalah; (2) menggunakan penalaran pada pola dan sifat, melakukan manipulasi matematika dalam membuat generalisasi, menyusun bukti, atau menjelaskan gagasan dan pernyataan matematika; (3) memecahkan masalah yang meliputi kemampuan memahami masalah, merancang model matematika, menyelesaikan model, dan menafsirkan solusi yang diperoleh; (4) mengkomunikasikan gagasan dengan simbol, tabel, dan diagram atau media 
lain untuk memperjelas keadaan atau masalah; (5) memiliki sikap menghargai kegunaan matematika dalam kehidupan yaitu memiliki rasa ingin tahu, perhatian dan minat dalam mempelajari matematika, serta sikap ulet dan percaya diri dalam pemecahan masalah (BSNP, 2006: 2). Sesuai dengan tujuan pertama matematika di atas, hal pertama yang harus dikuasai oleh siswa adalah pemahaman terhadap konsep-konsep yang akan melahirkan teorema atau rumus. Agar konsep itu dapat diaplikasikan ke situasi yang lain, perlu adanya keterampilan menggunakan konsep tersebut. Menurut Kilpatric (dalam Afgani, J, 2011: 2.21), "Pemahaman konseptual disebut juga pemahaman matematika". Dengan demikian, salah satu kemampuan yang harus dimiliki oleh siswa setelah belajar matematika adalah kemampuan pemahaman matematis.

Berdasarkan hasil wawancara dan observasi dengan guru matematika kelas XI IPS SMA Islam As-Shofa Pekanbaru yang penulis lakukan pada tanggal 5 November 2013, diperoleh kesimpulan sebagai berikut: (1) hasil belajar matematika siswa masih rendah, terdapat 13 siswadari 22 siswa yang mencapai KKM yaitu 78; (2) hanya beberapa siswa yang mampu menyelesaikan semua soal yang diberikan guru; (3) siswa masih kurang fokus dalam pembelajaran. Berdasarkan hasil observasi diketahui bahwa (1) pembelajaran masih didominasi oleh guru; (2) hanya sebagian siswa yang fokus mengikuti pembelajaran; (3) siswa masih lemah dalam mengungkapkan kembali materi yang diajarkan ke dalam tulisan atau bahasa sendiri apa yang diketahui; (4) siswa kesulitan dalam menyatakan ulang konsep yang dipelajari; (5) kelompok yang dibuat guru tidak berdasarkan tingkat kemampuan siswa, melainkan berdasarkan tempat duduk. Setelah peneliti mengadakan Tes Awal Kemampuan Pemahaman Matematis (TKPM) pada tanggal 26 Februari 2014 pada materi Fungsi Komposisi, diperoleh bahwa rata-rata kelas pada tes awal adalah 52,43 yang termasuk kriteria cukup.

Oleh karena itu, perlu dilakukan peningkatan kemampuan pemahaman matematis dengan melakukan perubahan-perubahan dalam pembelajaran. Perlunya dirancang suatu pembelajaran yang memungkinkan siswa untuk mengkonstruksi sendiri pengetahuannya, sehingga siswa lebih mampu mengkomunikasikan pemikirannya baik dengan guru, teman maupun terhadap materi matematika itu sendiri. Salah satu cara yang dapat dilakukan untuk meningkatkan pemahaman matematis adalah dengan melaksanakan strategi pembelajaran yang relevan dan inovasi untuk diterapkan oleh guru. Proses mengalami langsung apa yang sedang dipelajari akan mengaktifkan lebih banyak indera jika dibandingkan hanya mendengarkan orang lain/guru menjelaskan. Hal ini dipertegas oleh Yamin, M (2008: 54), bahwa "Kita belajar hanya 10\% dari apa yang kita baca, 20\% dari apa yang kita dengar, 30\% dari apa yang kita lihat, 50\% dari apa yang kita lihat dan dengar, 70\% dari apa yang kita katakan, dan 90\% dari apa yang kita katakan dan lakukan". Hal ini menunjukkan bahwa jika mengajar dengan banyak berceramah, maka tingkat pemahaman siswa hanya 20\%, tetapi sebaliknya, jika siswa diminta untuk melakukan sesuatu sambil mengkomunikasikan, tingkat pemahaman siswa dapat mencapai sekitar 90\%.

Salah satu strategi yang cocok digunakan untuk meningkatkan pemahaman matematis adalah strategi Think-Talk-Write (TTW). TTW merupakan salah satu bagian dari pembelajaran kooperatif (Lie, 2007). Dalam pembelajaran kooperatif, siswa melakukan kerjasama dengan aturan kelompok untuk mencapai tujuan yang ingin dicapai (Amir MZ, 2017). Pembelajaran dilakukan dalam kelompok heterogen dengan 3-5 siswa. Dalam kelompok ini siswa diminta membaca, membuat catatan kecil, menjelaskan, mendengar dan membagi ide bersama teman kemudian mengungkapkannya melalui tulisan dan (Trianto, 2007). Tujuan yang ingin dicapai dalam penelitian ini adalah untuk memperbaiki proses pembelajaran matematika dan dapat meningkatkan kemampuan pemahaman matematis 
siswa kelas XI IPS SMA Islam As-Shofa Pekanbaru pada materi limit dan turunan fungsi tahun ajaran 2013/2014 melalui implementasi strategi TTW.

\section{METODE PENELITIAN}

Bentuk penelitan ini adalah Penelitian Tindakan Kelas (PTK). Menurut Sanjaya, W (2011: 27) "PTK adalah rangkaian kegiatan tindakan dari mulai menyadari adanya masalah, kemudian tindakan untuk memecahkan masalah dan refleksi terhadap tindakan yang telah dilakukan". Dalam penelitian ini, guru bertindak sebagai pelaksana tindakan pada kelas yang dijadikan sebagai subjek dan peneliti sebagai pengamat selama proses pembelajaran melalui strategi TTW. Penelitian ini dilakukan dua siklus. Siklus pertama terdiri dari 4 kali pertemuan ditambah 1 kali Tes Kemampuan Pemahaman Matematis (TKPM) 1, siklus kedua terdiri dari 5 kali pertemuan ditambah 1 kali TKPM 2. Pada siklus pertama akan dilakukan tindakan sesuai dengan strategi TTW. Selanjutnya, siklus kedua merupakan tindakan yang akan dilakukan berdasarkan hasil refleksi dari sikus pertama.

Instrumen penelitian terdiri dari perangkat pembelajaran berupa silabus, Rencana Pelaksanaan Pembelajaran (RPP), dan Lembar Kerja Siswa (LKS), serta instrumen pengumpulan data yang terdiri dari lembar pengamatan aktivitas guru dan siswa dan tes kemampuan pemahaman matematis. Teknik pengumpulan data pada penelitian ini adalah teknik pengamatan, teknik tes dan dokumentasi. Data dianalisis secara deskriptif. Setiap indikator Kemampuan Pemahaman Matematis (KPM), dianalisis dengan rata-rata, persentase, dan analisis daftar distribusi frekuensi.

Rumus yang digunakan untuk menghitung persentase skor tiap indikator adalah:

$$
\text { Persentase skor }=\frac{\text { Skar yang diperoteh }}{\text { Skar Maksimal }} \times 100 \%
$$

Dari hasil perhitungan di atas, kemudian dikualifikasi dengan penentuan kriteria berpedoman pada salah satu cara menyusun kriteria oleh Arikunto (2009), yaitu kriteria kuantitatif tanpa pertimbangan. Selain itu, Arikunto, menjelaskan bahwa kriteria ini disusun hanya dengan mempertimbangkan rentang bilangan tanpa mempertimbangkan apa-apa, dilakukan dengan membagi rentang bilangan. Beliau membagi kriteria menjadi 5 yaitu Tinggi Sekali, Tinggi, Cukup, Rendah dan Rendah Sekali. Rentang yang digunakan adalah $100-0=100$. Kemudian rentang tersebut dibagi lima. Sehingga diperoleh interval sebagai berikut:

1. Interval 0-20 untuk kriteria Rendah Sekali

2. Interval 21-40 untuk kriteria Rendah

3. Interval 41-60 untuk kriteria Cukup

4. Interval 61-80 untuk kriteria Tinggi

5. Interval 81-100 untuk kriteria Tinggi Sekali

Berdasarkan pendapat di atas, maka peneliti membuat kriteria kemampuan pemahaman matematis sepertiberikutini:

Tabel 1. Kriteria Kemampuan Pemahaman Matematis

\begin{tabular}{cc}
\hline Persentase (\%) & Kriteria \\
\hline $0,00 \leq \%<20,00$ & Rendah Sekali \\
\hline $20,00 \leq \%<40,00$ & Rendah \\
\hline $40,00 \leq \%<60,00$ & Cukup \\
\hline $60,00 \leq \%<80,00$ & Tinggi \\
\hline $80,00 \leq \% \leq 100,00$ & Tinggi Sekali \\
\hline
\end{tabular}

berikut:

Menurut Sudjana, (2006: 67) rumus rata-rata dapat dihitung dengan cara sebagai 
Keterangan:

$$
\bar{X}=\frac{\sum X_{i}}{N}
$$

$\begin{array}{ll}\bar{X} & \text { : Rata-rata } \\ \sum_{N} X_{i} & : \text { Jumlah Nilai Seluruh Siswa } \\ N & \text { : Banyaknya Siswa }\end{array}$

\section{HASIL PENELITIAN DAN PEMBAHASAN}

Setelah dilakukan analisis data tentang penerapan strategi Think Talk Write pada materi limit fungsi dan turunan fungsi, dapat dilihat bahwa adanya perbaikan proses pembelajaran dan peningkatan kemampuan pemahaman matematis siswa kelas XI SMA Islam As-Shofa Pekanbaru. Hal ini terlihat dari aktivitas guru dan siswa serta persentase kemampuan pemahaman matematis siswa yang mengalami peningkatan dari Tes Awal ke TKPM I dan dari TKPM I ke TKPM II.

Tabel 2. Rata-rata KPM pada Tes Awal, TKPM I dan TKPM II

\begin{tabular}{lcccc}
\hline & Tes Awal & TKPM I & TKPM II \\
\hline $\begin{array}{l}\text { Jumlah Nilai semua } \\
\text { banyak-nya siswa }\end{array}$ & Indikator/ & $1.153,57 / 22$ & $1.541,66 / 22$ & $1.725 / 22$ \\
\hline Rata-rata nilai KPM & 52,43 & 70,08 & 78,41 \\
\hline Kriteria & Cukup & Tinggi & Tinggi \\
\hline
\end{tabular}

Rata-rata kelas kemampuan pemahaman matematis siswa pada Tes Awal adalah 52,43 meningkat menjadi 70,08 pada TKPM I, dan meningkat menjadi 78,41pada TKPM II. Sehingga dapat disimpulkan bahwa kemampuan pemahaman matematis secara keseluruhan mengalami peningkatan mulai dari Tes Awal ke TKPM I dan begitu juga dari TKPM I ke TKPM II dengan kriteria kemampuan pemahaman matematis pada TKPM II adalah tinggi sehingga memberikan dampak positif terhadap peningkatan kemampuan pemahaman matematis siswa kelas XI IPS SMA Islam As-Shofa Pekanbaru melalui penerapan strategi TTW.

Jumlah siswa untuk setiap kriteria yang telah dianalisis dengan daftar distribusi frekuensi dapat digambarkan dalam poligon di bawah ini:

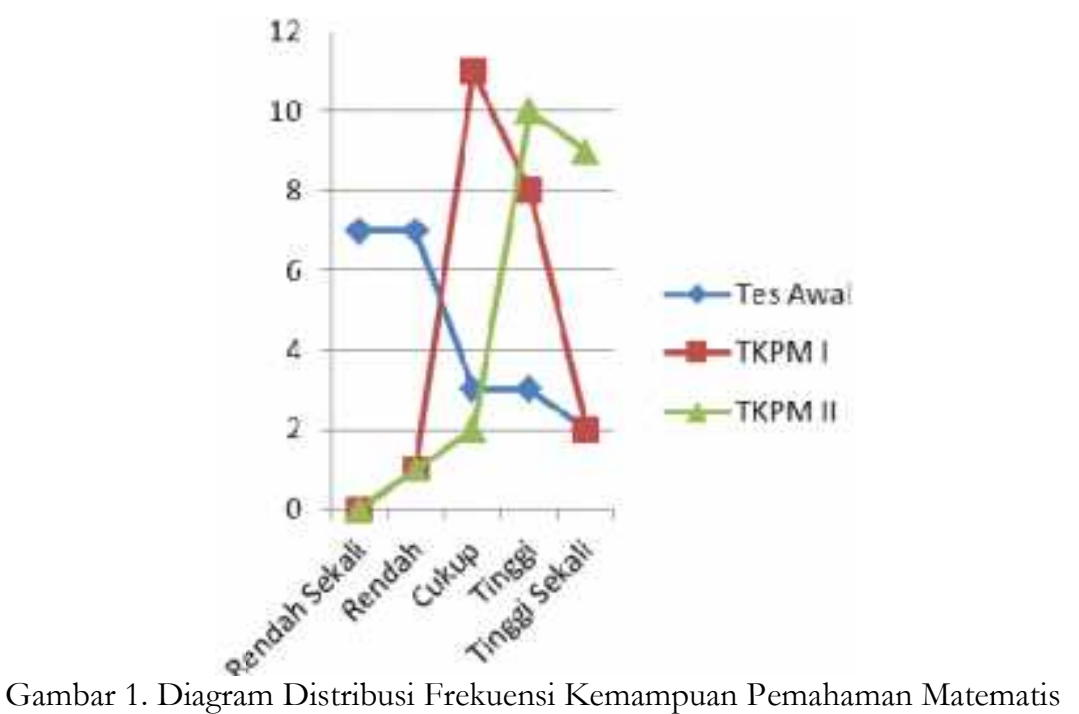


Dari diagram di atas, terlihat bahwa terjadi peningkatan jumlah siswa yang termasuk dalam kriteria sangat tinggi, yaitu pada tes awal 2 siswa, pada tes kemampuan pemahaman matematis I 2 siswa, dan pada tes kemampuan pemahaman matematis II 9 siswa, sebaliknya terjadi penurunan jumlah siswa yang termasuk dalam kriteria sangat rendah, yaitu pada tes awal 7 siswa, tidak ada siswa yang masuk dalam kriteria sangat rendah, pada tes kemampuan pemahaman matematis I, dan II.

Dengan diterapkannya strategi TTW ini, siswa dilibatkan secara aktif dalam menyelesaikan tugas dan tanggung jawab yang diberikan guru yang berupa lembaran kerja siswa (LKS). Selama bekerja dalam kelompok, tugas anggota kelompok adalah meningkatkan kemampuan pemahaman matematis terhadap soal yang disajikan guru dan saling membantu diantara teman sekelompok untuk mencapai yang diinginkan.

Kemudian berdasarkan pengamatan peneliti terhadap aktivitas siswa, terlihat siswa sudah berpartisipasi dalam proses pembelajaran dan berusaha mengikuti setiap aktivitas. Siswa sudah bisa menuangkan materi yang dipelajari ke dalam bentuk tulisan dengan kalimat mereka masing-masing, berdiskusi dengan teman sekelompoknya dengan baik, dan siswa juga sudah berani mengeluarkan pendapat tentang hasil presentasi temannya dan memberi tanggapan terhadap hasil kerja temannya. Hal ini sesuai dengan pendapat Gunawan, A (2012:82-83), "Salah satu strategi yang efektif untuk membuat materi pelajaran masuk akal dan relevan dalam suatu proses pembelajaran adalah dengan cara menjelaskan apa yang telah mereka pelajari dengan menggunakan kata-kata mereka sendiri". Amir MZ dan Wahyudin (2016) menyatakan bahwa dengan mengungkapkan kata-kata sendiri membuat siswa menyadari pemikiran mereka sendiri dan dapat meningkatkan proses kognitif siswa.

Berdasarkan uraian di atas, dapat disimpulkan bahwa kemampuan pemahaman matematis dapat ditingkatkan melalui penerapan strategi pembelajaran Think Talk Write. Jadi, hasil analisis tindakan ini mendukung hipotesis tindakan yang diajukan yaitu penerapan pembelajaran dengan strategi Think Talk Write dapat memperbaiki proses pembelajaran dan meningkatkan kemampuan pemahaman matematis siswa kelas XI IPS SMA Islam As-Shofa Pekanbaru. Hasil penelitian ini senada dengan hasil riset oleh Inayah (2008). Inayah menjelaskan bahwa strategi TTW dapat meningkatkan prestasi belajar matematika siswa

Kelemahan-kelemahan penelitian ini adalah Pada pelaksanaan tindakan penelitian, kelemahan peneliti yaitu peneliti kurang cermat mengelola waktu, sehingga pelaksanaan stretegi TTW tidak maksimal, seperti tidak setiap pertemuan dibahasnya Tes Individu dan nilai Tes Individupun tidak diumumkan. Pada penelitian ini ada dua orang pengamat, tetapi pengamat II selain mengamati aktivitas siswa, juga sebagai dokumentasi. Ini berpengaruh pada proses pengamatan, pengamat II bisa saja tidak fokus dalam mengamati aktivitas siswa. Namun, berdasarkan lembar pengamatan dan analisis data diperoleh bahwa terjadi perbaikan proses pembelajaran dan peningkatan kemampuan pemahaman matematis dari skor dasae ke siklus I dan siklus I ke siklus II.

\section{KESIMPULAN}

Berdasarkan pembahasan penelitian dalam dua siklus dan hasil analisis data yang telah dilakukan, dapat disimpulkan bahwa Berdasarkan hasil penelitian pada siklus I dan siklus II, maka dapat diambil kesimpulan bahwa penerapan strategi pembelajaran Think Talk Write (T'TW) dapat memperbaiki proses pembelajaran dan meningkatkan kemampuan pemahaman matematis siswa kelas XI IPS SMA Islam As-Shofa Pekanbaru tahun ajaran 2013/2014 pada materi limit fungsi dan turunan fungsi. 


\section{REFERENSI}

Afgani, J. (2011). Analisis Kurikulum Matematika. Jakarta: Universitas Terbuka.

Amir MZ, Zubaidah \& Wahyudin. (2016). Exploration of Metacognitive Ability at Elementary School Students in Learning Mathematics (Case Study in 1th Grade Students of Elementary School). Journal of Innovative Technology and Education, Vol. 3, 2016, no. 1, 179-184. HIKARI Ltd, www.m-hikari.com. http://dx.doi.org/10.12988/jite.2016.68

Amir MZ, Zubaidah (2017). Strategi Metakognitif dalam Pembelajaran Matematika. JPPM Vol. 10 No. 12017.

Arikunto, S. (2009). Penelitian Tindakan Kelas. Jakarta: Bumi Aksara.

BSNP. (2006). Bahan Ajar Telaah Kurikulum Matematika SMA. Pekanbaru.

Gunawan, A. (2012). Genius Learning Strategy. Jakarta: Gramedia.

Lie, Anita, (2007). Cooperative Learning, Jakarta, Grasindo.

Sanjaya, W. (2010). Kurikulum dan Pembelajaran. Jakarta: Kencana Prenada Media Group.

Sudjana. (2006). Metoda Statistika. Bandung: Tarsito.

Trianto (2007). Model-Mode IPembelajaran Inovatif Berorientasi Konstruktivistik, Jakarta: Prestasi Pustaka Yamin, M. (2008). Taktik Mengembangkan Kemampuan Individual Siswa. Jakarta: Referensi. 